\title{
Floristic Composition Analysis of Soil Transposition in a Seasonal Forest in Rio Grande do Sul, Brazil
}

\author{
Bruna Balestrin Piaia ${ }^{1}$ (D), Ana Paula Moreira Rovedder ${ }^{2}$ (D), Eliara Marin Piazza ${ }^{1}$ (D), \\ Maureen de Moraes Stefanello ${ }^{3}$ (D), Roselene Marostega Felker ${ }^{1}$ (D), \\ Emanuel Arnoni Costa ${ }^{1}$ \\ ${ }^{1}$ Programa de Pós-graduação em Engenharia Florestal, Universidade Federal de Santa Maria - UFSM, \\ Santa Maria/RS, Brasil \\ ${ }^{2}$ Departamento de Engenharia Florestal, Universidade Federal de Santa Maria - UFSM, Santa Maria/RS, Brasil \\ ${ }^{3}$ Programa de Pós-graduação em Engenharia Agrícola, Universidade Federal de Santa Maria - UFSM, \\ Santa Maria/RS, Brasil
}

\begin{abstract}
This study aimed to identify the floristic composition and density of a seed bank transposed from a Seasonal Forest fragment in Rio Grande do Sul. The seed bank of the (BSI) fragment center and edge (BSII) of another forest fragment was also evaluated, both at medium to advanced successional stages. The seed bank was deposited in Brown-Gray Argisol and Red Argisol using exposed soil plots as control. ANOVA followed by Tukey test $(\mathrm{p}<0.05)$ were used to compare treatments for density and species richness. The density of individuals did not differ between treatments. Species richness was higher for BSI and BSII treatments in relation to control. The floristic composition presented different life forms, but was mainly composed of herbaceous species. It was concluded that the seed bank from the two donor areas contributed to the expansion of species richness in two soil types.
\end{abstract}

Keywords: degraded areas, nucleation, seed bank transposition. 


\section{INTRODUCTION}

Nucleation strategies for ecological restoration are promising because they initiate or facilitate secondary succession processes (Corbin \& Holl, 2012). Seed bank transposition is a nucleation technique that consists of removing the superficial soil layer and litter from a conserved donor area for later deposition on a degraded area with the same vegetal typology (Reis et al., 2014). This superficial soil layer deposited on a degraded area serves as seed source, and can introduce abundance and species richness, thus establishing a new successional pattern (Zhang et al., 2001; Hall et al., 2010).

Soil transposition may increase the diversity of regional native species, genetic variability, and the chances of recruiting species adapted to adverse conditions (Reis et al., 2003; He et al., 2016). In this sense, many authors have emphasized the use of the seed bank as an efficient strategy for covering degraded or disturbed areas by including species of different forms of plant life (Tozer et al., 2012; Ferreira et al., 2015; Fowler et al., 2015).

However, there is still lack of scientific information regarding the technique specificities (Corbin \& Holl, 2012; Boanares \& Azevedo, 2014), mainly in the southern region of Brazil, which is strongly influenced by subtropical climate (Rovedder et al., 2014). There is also a worrying scenario of habitat fragmentation, loss of biological diversity and risk of species extinction due to anthropogenic activities related to poorly managed agriculture, livestock and urbanization (Monteiro \& Blauth, 2006). This scenario highlights the increasing need for validating and inserting ecological restoration methodologies for the region.

In this context, the aim of this study was to identify the floristic composition and density of a seed bank transposed from the center and edge of Seasonal Forest fragments deposited in two different soil types in the central region of Rio Grande do Sul in order to generate subsidies to adapt this ecological restoration technique to subtropical conditions.

\section{MATERIAL AND METHODS}

This study was carried out in Santa Maria ( $29^{\circ} 41^{\prime} 03^{\prime \prime} \mathrm{S}$ and $53^{\circ} 48^{\prime} 25^{\prime \prime} \mathrm{W}$ ), in the central region of Rio Grande do Sul. The average altitude is $103 \mathrm{~m}$ above sea level and the climate is Cfa, according to the Köppen climate classification, being subtropical humid with hot summer and without defined dry season. The average temperature of the coldest month is $13.3^{\circ} \mathrm{C}$, and the hottest month is $24.5^{\circ} \mathrm{C}$. The average monthly rainfall ranges from $134 \mathrm{~mm}$ to $192 \mathrm{~mm}$ (Alvares et al., 2013). The relief is smooth-waved and soils are derived from sandstones with siltite and argillite stratification, with Argisols predominating in elevations and middle third of slopes, and Planosols and Gleysols in lower altitudes (Streck et al., 2008). The region is an ecotonal transition zone between Pampa and Mata Atlântica Biomes. The characteristic forest formation is subtropical Seasonal Forest. Low temperatures in the winter cause physiological rest and partial leaf deciduousness (IBGE, 2012).

We selected two forest fragments for soil collection based on preliminary seed bank analysis under greenhouse conditions (Piaia et al., 2017b). Forest fragments donors are in an agricultural production matrix, showing pastures and annual crops in the surroundings. In order to characterize the floristic composition of each fragment, a floristic assessment of the arboreal stratum was carried out using the quadrant method (Moro \& Martins, 2011; Freitas \& Magalhães, 2012). Thus, points were systematically distributed in line with $20 \mathrm{~m}$ distance between each point. Thus, the seed bank donor forests were described below:

- Seed bank of the forest center (SBI): samples were removed from the center (distance $\geq 50 \mathrm{~m}$ from the forest edge) of Seasonal Forest remnant at medium to advanced successional stages, with average canopy height of $8.5 \mathrm{~m}$. The fragment has rectangular shape and $25 \mathrm{ha}$. Overall, 16 species were observed by the quadrant point method, and the four species with the highest frequency were Actinostemon concolor (Spreng.) Müll. Arg., Eugenia ramboi D. Legrand, Plinia rivularis (Cambess.) Rotman. and Myrcianthes pungens (O.Berg) D. Legrand;

- Seed bank of the forest edge (SBII): samples were removed from the edge (distance $\leq 10 \mathrm{~m}$ from the forest edge) of a Seasonal Forest remnant at medium to advanced successional stage, with average canopy height of $12 \mathrm{~m}$. The fragment has circular shape and 30 ha. Overall, 10 species were recorded by the quadrant point method. Actinostemon concolor (Spreng.) Müll.Arg., Eugenia ramboi D. Legrand, Plinia rivularis (Cambess.) Rotman. and Campomanesia xanthocarpa O. Berg. were the four species with the highest frequencies. 
The seed bank was removed with $1 \mathrm{mx} 1 \mathrm{~m}$ template and $5 \mathrm{~cm}$ in depth in 12 points in each area at the beginning of December 2013, corresponding to the end of spring, which is a period of higher seed deposition (Longhi et al., 2005). Collection was performed in a systematized way with $20 \mathrm{~m}$ of distance between transect points. Each sample was stored in a plastic bag, where litter was stored separately, receiving the same identification. Subsequently, samples were taken to the experimental area of the Department of Forestry Sciences - Federal University of Santa Maria. Donor forests and seed bank deposition site are approximately $10 \mathrm{~km}$ from each other.

Soils of the deposition site were classified as Brown-Grey Argisol (PBAC) and Red Argisol (PV), according to the Brazilian Soil Classification System (EMBRAPA, 2013), consisting of pedsequences typical of the Central Depression of RS, both occurring from flat to soft-wavy relief. PBAC presents hydromorphic character, with formation of water slides during periods of intense rainfall. It originates from siltstones and argillites, and occupies the intermediate portion of the relief. PV occurs in the same toposequence of "Coxilhas", occupying the highest portion of the relief (Streck et al., 2008).

In PBAC, there was predominance of species from the Poaceae botanical family such as Paspalum sp. and exotic Eragrostis plana Nees (annoni-grass), with presence of species from Apiaceae (Eryngium sp.) and Cyperaceae families which are characteristic of humid environments. In PV, there was predominance of species from the Poaceae family such as Paspalum sp. and exotic Eragrostis plana Nees (annoni-grass). However, the presence of Apiaceae or Cyperaceae was not observed in PV. Both soils presented pasture as land use history, with annual crops such as soybean and eucalyptus plantations in their surroundings.

Treatments consisted of two seed bank donor sites (SBI and SBII) deposited in two soil types (PBAC and PV), plus control treatments $(\mathrm{C})$ on both soils, so there were six treatments (SBI/PBAC, SBII/PBAC, C/PBAC, $\mathrm{SBI} / \mathrm{PV}, \mathrm{SBII} / \mathrm{PV}, \mathrm{C} / \mathrm{PV}$ ) with six replicates, each in a completely randomized experimental design.

Seed bank distribution was random in $1 \mathrm{~m}^{2}$ plots, with minimum distance of $5 \mathrm{~m}$ between each other. Vegetation and superficial soil were previously removed from plots so local regenerating plants would be excluded.
Thus, soil and litter were deposited, corresponding to that sample. Control treatment $(\mathrm{C})$ had only vegetation and surface soil of the $1 \mathrm{~m}^{2}$ plots removed, therefore consisting of the exposed soil without receiving the seed bank.

The seed bank transposition was assessed for twelve months from January to December 2014. Seedlings that emerged with serially numbered metal plates were identified. The APG III (APG, 2009) classification system was adopted and the names of species were confirmed through the Missouri Botanical Garden website (Tropicos.org, 2016).

Seedlings were classified as life forms in herbaceous, sub-shrubs, shrubs, trees and climbing plants. The diversity index of Shannon $\left(\mathrm{H}^{\prime}\right)$ and the evenness of Pielou (Magurran, 2013) were then calculated. Subsequently, the calculated H' values were compared by the Hutcheson t-test at $5 \%$ probability level. This test verifies the difference between diversity indexes for two samples, therefore comparisons were performed in pairs (Hutcheson, 1970).

Density, species richness and density by life form data were submitted to the Kolgomorov-Smirnov test to verify normality and the Bartlett test for homogeneity of variance, and when assumptions were not recognized, non-parametric statistical analysis was performed.

Differences in treatments for density and species richness wre evaluated using ANOVA, and comparisons were performed by the Tukey test $(\mathrm{p}<0.05)$. Treatments for density by life form were also compared using the Kruskal-Wallis test $(\mathrm{p}<0.05)$. When significant difference between treatments was observed, they were compared by the t-test $(\mathrm{p}<0.05)$ (Triola, 1999), according to the agricolae package of the $\mathrm{R}$ software (Mendiburu, 2015; R Development Core Team, 2013).

Cluster analysis was performed using the Ward linking method with presence and absence of data for the species with the STATISTICA software version 10 to verify the floristic similarity between treatments.

\section{RESULTS AND DISCUSSION}

Overall, 1,461 individuals from 25 botanical families, 76 genus and 85 species were sampled. Of these 85 species, eight were identified at the botanical family level and 19 were not determined, registered as morphospecies (Table 1). The number of unidentified 
Table 1. Number of individuals by species found in transposed seed bank (SBI and SBII) and control (C) in Brown-Grey Argisol (PBAC) and Red Argisol (PV) soil types in Santa Maria, RS.

\begin{tabular}{|c|c|c|c|c|c|c|c|c|}
\hline \multirow{2}{*}{ Family/species } & \multirow{2}{*}{ LF } & \multicolumn{4}{|c|}{ PBAC } & \multicolumn{3}{|c|}{ PV } \\
\hline & & SBI & SBII & C & Tot & SBI & SBI & \\
\hline
\end{tabular}

\section{Acanthaceae}

Acantaceae sp. 1

$\begin{array}{lll}\text { her } & 1 & 1\end{array}$

\section{Amaranthaceae}

Amaranthus hybridus L.

Pfaffia tuberosa (Spreng.) Hicken

her 1

\section{Apiaceae}

Centella asiatica (L.) Urb.

Eryngium sp.

her

1

Araliaceae

\begin{tabular}{|c|c|c|c|c|c|c|c|c|c|}
\hline & & & & & & & & & \\
\hline Hydrocotyle sp. & her & 5 & 6 & & 11 & 1 & 2 & 2 & 5 \\
\hline \multicolumn{10}{|l|}{ Asteraceae } \\
\hline Ageratum conyzoides L. & her & 1 & & & 1 & 6 & 1 & & 7 \\
\hline Baccharis coridifolia DC. & subsh & 16 & 9 & 1 & 26 & & & & \\
\hline Baccharis dracunculifolia DC. & sh & & 1 & & 1 & & & & \\
\hline Baccharis sp. & sh & & & 1 & 1 & & & 1 & 1 \\
\hline Conyza sp. & her & 1 & & 1 & 2 & 9 & 17 & 2 & 28 \\
\hline Elephantopus mollis Kunth & her & & & & & 1 & 5 & 2 & 8 \\
\hline Erechtites hieraciifolius (L.) Raf. ex DC. & her & 3 & 4 & 2 & 9 & 1 & 3 & 1 & 5 \\
\hline Eupatorium ivifolium L. & her & 54 & 82 & 79 & 215 & 12 & 2 & 5 & 19 \\
\hline Eupatorium laevigatum Lam. & sh & 8 & 2 & 1 & 11 & & & & \\
\hline Eupatorium macrocephalum Less. & her & 2 & 9 & 2 & 13 & 3 & & & 3 \\
\hline Facelis retusa (Lam.) Sch. Bip. & her & & & & & 2 & 4 & 3 & 9 \\
\hline Gamochaeta pensylvanica (Wild.) Cabrera & her & 18 & 19 & & 37 & 6 & 5 & 3 & 14 \\
\hline Hypochaeris radicata $\mathrm{L}$. & her & & 3 & & 3 & 1 & 2 & 5 & 8 \\
\hline Picrosia longifolia D. Don & her & & & & & & 1 & & 1 \\
\hline Pluchea sagittalis (Lam.) Cabrera & her & & 1 & & 1 & & & & \\
\hline Senecio brasiliensis (Spreng.) Less. & her & & & & & 1 & 2 & & 3 \\
\hline Solidago chilensis Meyen & her & & 5 & & 5 & & & & \\
\hline Sonchus oleraceus L. & her & & 3 & & 3 & & & & \\
\hline Vernonanthura tweedieana (Baker) H. Rob. & sh & 15 & 3 & 2 & 20 & 29 & 2 & 8 & 39 \\
\hline Vernonia nudiflora Less. & subsh & & & & & & 5 & & 5 \\
\hline Asteraceae sp. 1 & her & 9 & 4 & 3 & 16 & 3 & 6 & 3 & 12 \\
\hline Asteraceae sp. 2 & her & & & 3 & 3 & & & & \\
\hline Asteraceae sp. 3 & her & & 1 & & 1 & & & & \\
\hline Asteraceae sp. 4 & her & & & & & 1 & 11 & 5 & 17 \\
\hline Asteraceae sp. 5 & her & & & 1 & 1 & & & & \\
\hline Asteraceae sp. 6 & her & & & 1 & 1 & & & & \\
\hline Asteraceae sp. 7 & her & & 1 & & 1 & 1 & & & 1 \\
\hline \multicolumn{10}{|l|}{ Convolvulaceae } \\
\hline Ipomoea purpurea (L.) Roth. & $\mathrm{cl}$ & 25 & 19 & 35 & 79 & 32 & 16 & 65 & 113 \\
\hline Ipomoea sp. & $\mathrm{cl}$ & 5 & 1 & 3 & 9 & 1 & 1 & 1 & 3 \\
\hline \multicolumn{10}{|l|}{ Cyperaceae } \\
\hline Cyperus sp. & her & 2 & 3 & 3 & 8 & & & & \\
\hline Kyllinga brevifolia Rottb. & her & 1 & 1 & 1 & 3 & 1 & & 1 & 2 \\
\hline \multicolumn{10}{|l|}{ Euphorbiaceae } \\
\hline Actinostemon concolor (Spreng.) Müll.Arg. & $\operatorname{tr}$ & 10 & 22 & & 32 & 3 & 3 & & 6 \\
\hline Gymnanthes klotzschiana Müll. Arg. & $\operatorname{tr}$ & & 1 & & 1 & 1 & & & 1 \\
\hline Sebastiania brasiliensis Spreng. & $\operatorname{tr}$ & & 2 & & 2 & & & & \\
\hline
\end{tabular}

Which: $\mathrm{LF}=$ Life form; her = herbaceous; subsh = sub-shrubs; $\mathrm{sh}=$ shrubs; $\mathrm{tr}=\mathrm{trees} ; \mathrm{cl}=$ climbing plants; Tot. $=$ Total. 
Table 1. Continued...

\begin{tabular}{|c|c|c|c|c|c|c|c|c|c|}
\hline \multirow{2}{*}{ Family/species } & \multirow{2}{*}{ LF } & \multicolumn{4}{|c|}{ PBAC } & \multicolumn{4}{|c|}{ PV } \\
\hline & & SBI & SBII & $\mathbf{C}$ & Tot & SBI & SBII & $\mathbf{C}$ & Tot \\
\hline \multicolumn{10}{|l|}{ Fabaceae } \\
\hline Desmodium sp. & her & 8 & 11 & 1 & 20 & 3 & 12 & 5 & 20 \\
\hline \multicolumn{10}{|l|}{ Iridadecae } \\
\hline Sisyrinchium alatum Hook. & her & & & & & & 1 & & 1 \\
\hline Sisyrinchium micranthum Cav. & her & 5 & 2 & 1 & 8 & & & & \\
\hline \multicolumn{10}{|l|}{ Lamiaceae } \\
\hline Hyptis sp. & her & & & & & 1 & & & 1 \\
\hline \multicolumn{10}{|l|}{ Lythraceae } \\
\hline Cuphea carthagenensis (Jacq.) J. F. Macbr. & her & 6 & 4 & 10 & 20 & 1 & 1 & 1 & 3 \\
\hline \multicolumn{10}{|l|}{ Malvaceae } \\
\hline Sida sp. & her & 10 & 11 & 40 & 61 & 22 & 25 & 127 & 174 \\
\hline \multicolumn{10}{|l|}{ Melastomataceae } \\
\hline Tibouchina sp. & her & 2 & 8 & & 10 & & & & \\
\hline \multicolumn{10}{|l|}{ Moraceae } \\
\hline Sorocea bonplandii (Baill.) W.C. Burger oer & $\operatorname{tr}$ & & 1 & & 1 & & 1 & & 1 \\
\hline \multicolumn{10}{|l|}{ Myrtaceae } \\
\hline Eugenia uniflora L. & $\operatorname{tr}$ & 1 & & & 1 & & & & \\
\hline Psidium guajava $\mathrm{L}$. & $\operatorname{tr}$ & & & & & 1 & & & 1 \\
\hline \multicolumn{10}{|l|}{ Onagraceae } \\
\hline Ludwigia sp. & her & 11 & 6 & 11 & 28 & & 1 & & 1 \\
\hline \multicolumn{10}{|l|}{ Oxalidaceae } \\
\hline Oxalis brasiliensis Lodd. & her & 2 & 2 & & 4 & & & & \\
\hline \multicolumn{10}{|l|}{ Phyllanthaceae } \\
\hline Phyllanthus tenellus Roxb. & her & & & & & 3 & 1 & 1 & 5 \\
\hline \multicolumn{10}{|l|}{ Plantaginaceae } \\
\hline Plantago sp. & her & 3 & 2 & & 5 & & 1 & 1 & 2 \\
\hline Scoparia dulcis L. & her & & & & & 2 & & 1 & 3 \\
\hline \multicolumn{10}{|l|}{ Rubiaceae } \\
\hline Borreria eryngioides Cham. \& Schltdl. & her & & & & & 1 & & & 1 \\
\hline Richardia brasiliensis Gomes & her & & & & & & 1 & & 1 \\
\hline Spermacoce latifolia (Aubl.) K.Schum. & her & 5 & 4 & & 9 & & & 1 & 1 \\
\hline \multicolumn{10}{|l|}{ Rutaceae } \\
\hline Helietta apiculata Benth. & $\operatorname{tr}$ & 7 & 1 & & 8 & & 5 & & 5 \\
\hline \multicolumn{10}{|l|}{ Sapindaceae } \\
\hline Serjania sp. & $\mathrm{cl}$ & & & & & 2 & & & 2 \\
\hline Solanaceae & & & & & & & & & \\
\hline Solanum americanum Mill. & her & 4 & 4 & & 8 & 2 & 4 & 1 & 7 \\
\hline Solanum mauritianum Scop. & $\operatorname{tr}$ & 2 & 2 & & 4 & 2 & 2 & & 4 \\
\hline Solanum sisymbriifolium Lam. & her & 1 & 1 & & 2 & & & 2 & 2 \\
\hline Solanum viarum Dunal & her & & 2 & & 2 & & & & \\
\hline Verbenaceae & & & & & & & & & \\
\hline Glandularia aristigera (S. Moore) Tronc. & her & & & & & 4 & 3 & 2 & 9 \\
\hline Verbena rigida Spreng. & her & & & 2 & 2 & 1 & 1 & 1 & 3 \\
\hline Undetermined & & & & & & & & & \\
\hline Morphospecies 1 & her & & & 1 & 1 & & & & \\
\hline Morphospecies 2 & her & & & & & 1 & & & 1 \\
\hline Morphospecies 3 & her & 3 & 2 & 3 & 8 & & & & \\
\hline Morphospecies 4 & her & & & 1 & 1 & & & & \\
\hline
\end{tabular}

Which: LF = Life form; her = herbaceous; subsh = sub-shrubs; sh = shrubs; $\operatorname{tr}=$ trees; cl = climbing plants; Tot. = Total. 
Table 1. Continued...

\begin{tabular}{|c|c|c|c|c|c|c|c|c|c|}
\hline \multirow{2}{*}{ Family/species } & \multirow{2}{*}{ LF } & \multicolumn{4}{|c|}{ PBAC } & \multicolumn{4}{|c|}{ PV } \\
\hline & & SBI & SBII & C & Tot & SBI & SBII & C & Tot \\
\hline Morphospecies 5 & her & 2 & & 1 & 3 & & & & \\
\hline Morphospecies 6 & $\operatorname{tr}$ & & 1 & & 1 & & & & \\
\hline Morphospecies 7 & her & 1 & & & 1 & & & & \\
\hline Morphospecies 8 & her & & & & & & & 1 & 1 \\
\hline Morphospecies 9 & her & & & & & & & 1 & 1 \\
\hline Morphospecies 10 & her & & & & & & & 1 & 1 \\
\hline Morphospecies 11 & her & & & & & 1 & & & 1 \\
\hline Morphospecies 12 & her & & & & & 1 & & & 1 \\
\hline Morphospecies 13 & her & & & & & & & 1 & 1 \\
\hline Morphospecies 14 & her & & & & & 1 & & & 1 \\
\hline Morphospecies 15 & her & & & 1 & 1 & & & & \\
\hline Morphospecies 16 & her & & & & & & & 1 & 1 \\
\hline Morphospecies 17 & her & & & & & 1 & & & 1 \\
\hline Morphospecies 18 & her & & & & & 1 & & & 1 \\
\hline Morphospecies 19 & her & & & & & 1 & & & 1 \\
\hline Total & & 253 & 270 & 214 & 737 & 231 & 187 & 306 & 724 \\
\hline
\end{tabular}

Which: LF = Life form; her = herbaceous; subsh = sub-shrubs; $\mathrm{sh}=$ shrubs; $\mathrm{tr}=$ trees; $\mathrm{cl}=$ climbing plants; Tot. = Total.

species is related to the similar morphology of the initial development of herbaceous species and to the occurrence of low density of seedlings of the same morphospecies. Other studies also reported the difficulty in identifying seedling species from the seed bank (Sccoti et al., 2011; Calegari et al., 2013).

The most representative families were Asteraceae and Solanaceae, common in early succession stages (Miranda et al., 2010), a typical result of species that form the persistent seed bank. The species showing the highest number of individuals in the Brown-Grey Argisol (PBAC) were Eupatorium ivifolium L., Ipomoea purpurea (L.) Roth. and Sida sp.. In Red Argisol (PV), the most representative species were Pfaffia tuberosa (Spreng.) Hicken, Ipomoea purpurea and Sida sp. These species were found in all treatments with high density in the control in both PBAC and PV, which indicates the influence of an autochthonous seed bank.

Eupatorium is one of the main genus of shrub and sub-shrub species occurring throughout the southern portion of Rio Grande do Sul, together with Baccharis, Senecio and Vernonia (Rovedder, 2013), which also were registered in this study. This characterizes the ecotonal transition aspect of the central region of Rio Grande do Sul.

P. tuberosa presents occurrence in the Southern, Southeastern and Midwestern regions of Brazil, mainly inhabiting dry and sandy fields (Marchioretto et al.,
2009). This specie was not found in PBAC treatments of hydromorphic character. In fact, hydromorphy can be pointed out as an important ecological filter for seed bank expression (Piaia et al., 2017a). It could be exemplified by the high density of P. tuberosa in PV (densities of 10 ind. $/ \mathrm{m}^{2}$ in SBI, 6 ind. $/ \mathrm{m}^{2}$ in SBII and 8 ind. $/ \mathrm{m}^{2}$ in $\mathrm{C}$ were observed), and no individuals of this specie in PBAC.

I. purpurea and Sida sp. are ruderal species with large distribution in the Brazilian territory (Ferreira \& Miotto, 2009). They are able to grow under adverse conditions and have the ability to produce large numbers of seeds with efficient dispersion (Brighenti \& Oliveira, 2011).

The highest diversity was found in SBI/PBAC and $\mathrm{SBII} / \mathrm{PV}$, and control (C/PBAC and C/PV) showed the lowest diversity (Table 2). This means that the transposed seed bank increased diversity in both study sites. The absence of a defined pattern for floristic composition and diversity for fragment center and edge (BSI and BSII) may have occurred due to the spatial heterogeneity of the forest seed bank (Baider et al., 1999), and due to the influence of the environmental gradient responsible for the different compositions of species in the same fragment (Ferreira et al., 2012). In the same way, the deposition environment of the seed bank also acts as an ecological filter to express the floristic composition, as previously mentioned 
Table 2. Floristic richness, density, diversity and evenness indexes found in the transposed seed bank and control (SBI, SBII and C) in Brown-Grey Argisol (PBAC) and Red Argisol (PV) soil types in Santa Maria, RS.

\begin{tabular}{|c|c|c|c|c|c|c|c|c|}
\hline \multirow{2}{*}{ Variables } & \multicolumn{4}{|c|}{ PBAC } & \multicolumn{4}{|c|}{ PV } \\
\hline & SBI & SBII & C & Total & SBI & SBII & C & Total \\
\hline Total number of families & 19 & 18 & 11 & 22 & 18 & 17 & 14 & 22 \\
\hline Total number of species & 36 & 41 & 29 & 57 & 42 & 35 & 33 & 59 \\
\hline Total number of seedlings & 253 & 270 & 214 & 737 & 231 & 187 & 306 & 724 \\
\hline Species richness $/ \mathrm{m}^{2}$ & $14.3 \mathrm{a}^{*}$ & $14.3 \mathrm{a}$ & $9.2 \mathrm{~b}$ & - & $13.0 \mathrm{a}$ & $11.8 \mathrm{a}$ & $9.7 \mathrm{a}$ & - \\
\hline Density (ind./m²) & $42.2 \mathrm{a}$ & $45.0 \mathrm{a}$ & $35.7 \mathrm{a}$ & - & $38.5 \mathrm{ab}$ & $31.2 \mathrm{~b}$ & $51.0 \mathrm{a}$ & - \\
\hline Shannon - H' & $3.00 \mathrm{a}^{* *}$ & $2.32 \mathrm{~b}$ & $1.78 \mathrm{c}$ & - & $2.38 \mathrm{~b}$ & $2.88 \mathrm{a}$ & $1.67 \mathrm{c}$ & - \\
\hline Pielou - J’ & 0.84 & 0.62 & 0.53 & - & 0.64 & 0.81 & 0.48 & - \\
\hline
\end{tabular}

${ }^{*}$ Means followed by the same letter in the row by soil class do not differ by the Tukey test $(\mathrm{p}<0.05)$; ${ }^{*}$ Shannon index followed by the same letter do not differ by the Hutcheson's t-test $(\mathrm{p}<0.05)$.

Table 3. Density of individuals by life form (ind. $/ \mathrm{m}^{2}$ ) for each treatment (SBI, SBII and C) in Brown-Grey Argisol (PBAC) and Red Argisol (PV) in Santa Maria, RS, Brazil.

\begin{tabular}{cccccc}
\multirow{2}{*}{ Soil } & Treatments & \multicolumn{4}{c}{ Life forms } \\
\cline { 3 - 6 } & & Arboreal & Shrub & Herbaceous & Climbing plants \\
\cline { 3 - 6 } PBAC & SBI & $3.33 \mathrm{a}^{*}$ & $3.83 \mathrm{a}$ & $30.00 \mathrm{a}$ & $5.00 \mathrm{a}$ \\
& SBII & $5.00 \mathrm{a}$ & $1.00 \mathrm{a}$ & $35.67 \mathrm{a}$ & $3.33 \mathrm{a}$ \\
& C & $0.00 \mathrm{~b}$ & $0.67 \mathrm{a}$ & $28.67 \mathrm{a}$ & $6.33 \mathrm{a}$ \\
& SBI & $1.17 \mathrm{a}$ & $4.83 \mathrm{a}$ & $26.67 \mathrm{a}$ & $5.83 \mathrm{ab}$ \\
& SBII & $1.83 \mathrm{a}$ & $0.33 \mathrm{~b}$ & $26.17 \mathrm{a}$ & $2.83 \mathrm{~b}$ \\
& $\mathrm{C}$ & $0.00 \mathrm{~b}$ & $1.50 \mathrm{ab}$ & $38.50 \mathrm{a}$ & $11.00 \mathrm{a}$ \\
\hline
\end{tabular}

${ }^{*}$ Means followed by the same letter by life form and soil class do not differ by the Kruskal-wallis test $(\mathrm{p}<0.05)$.

with respect to soil hydromorphy. In this sense, it is important to highlight the appropriate choice of the seed bank collection site, where it should be stratified, close together and with similar conditions, for example in relation to the soil hydromorphy, to the site that needs to be restored.

Herbaceous life forms were predominant in all treatments in both soil classes (Table 3). Mechanisms such as capacity to develop under adverse conditions, production of large numbers of seeds, efficient dispersion over long distances, and dormancy and uneven germination are typical of this type of biological form, which again show the expression of the persistent seed bank (Long et al., 2015).

Pioneer herbaceous and shrub species are important in seed bank transposition projects for ecological restoration because they are generally aggressive and colonizing. They proportionate rapid soil cover and proliferate rapidly, attract pollinator fauna and seed dispersers, showing early senescence, preparing the environment for subsequent stages (Bechara et al., 2007).

Species of arboreal life forms were only found in plots where there was seed bank deposition in both soil types (Table 3 ), which evidences the potential of this technique to include arboreal life forms in restoration areas. Actinostemon concolor (Spreng.) Müll.Arg. presented the largest number of individuals for this life form in both soil types (Table 1). This species is understory, has autocory dispersion, and is usually found in aggregate distribution in the forest (Longhi et al., 2000). We emphasize that this was the most abundant species observed in the floristic survey carried out in forest fragments.

In PBAC, 28 species in SBI and SBII were sampled, which were not found in the control treatment; of these, seven species have arboreal behavior. In PV, there were 26 exclusive species in the deposition seed bank plots (SBI and SBII), five of which were arboreal life forms. This demonstrates and reinforces the effectiveness of transposition to increase the richness and insertion of other life forms in degraded areas, and that the collection in two donor sites, namely fragment center and edge, was important for this increase.

The dendrogram obtained by the cluster analysis demonstrates the heterogeneity of the floristic composition found in the nuclei of seed bank transposition and in the control treatment in both soil types (Figure 1). 


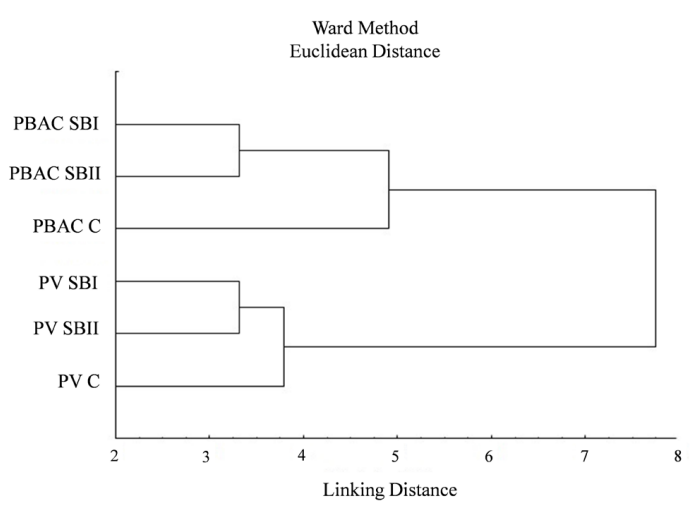

Figure 1. Dendrogram obtained by cluster analysis for the floristic composition of the transposed seed bank and control (SBI, SBII and C) in Brown-Grey Argisol (PBAC) and Red Argisol (PV) soil types in Santa Maria, RS, Brazil.

Closer bonds between SBI and SBII treatments within each deposition area were observed, which demonstrates the transposition effect, showing greater species richness compared to control. The main grouping distinction was observed between soil types (PBAC and PV), evidencing that the environmental characteristics influenced the floristic characteristics of regenerates; and in PBAC, having more hydromorphic character, the occurrence of species such as Ludwigia sp., Centella asiatica (L.) Urb., Eryngium sp., and Cuphea carthagenensis (Jacq.) J. F. Macbr. (Table 1) was observed, which are characteristics of humid environments (Boldrini et al., 2008).

\section{CONCLUSIONS}

- The conditions of the deposition site influenced by the seed bank composition were mainly influenced by the soil hydromorphic characteristics;

- Seed bank removed from the center and edge of the forest fragment at medium to advanced stage was efficient in increasing richness and diversity in both soil types where it was deposited;

- The seed bank transposition started the recovery and initial succession process in Brown-Grey Argisol and Red Argisol soil types.

\section{SUBMISSION STATUS}

Received: 15 feb., 2017

Accepted: 14 feb., 2018

\section{CORRESPONDENCE TO}

\section{Bruna Balestrin Piaia}

Universidade Federal de Santa Maria - UFSM, Av. Roraima, 1000, CEP 97105-900, Santa Maria, RS, Brasil

e-mail: brunabpiaia@gmail.com

\section{REFERENCES}

Alvares CA, Stape JL, Sentelhas PC, Gonçalves JLM, Sparovek G. Köppen's climate classification map for Brazil. Meteorologische Zeitschrift 2013; 22(6): 711-728. http:// dx.doi.org/10.1127/0941-2948/2013/0507.

Angiosperm Phylogeny Group - APG. An update of the Angiosperm Phylogeny Group classification for the orders and families of flowering plants: APG III. Botanical Journal of the Linnean Society 2009; 161(2): 105-121. http://dx.doi. org/10.1111/j.1095-8339.2009.00996.x.

Baider C, Tabarelli M, Mantovani W. O banco de sementes de um trecho de uma Floresta Atlântica Montana (São Paulo - Brasil). Revista Brasileira de Biologia 1999; 59(2): 319-328. http://dx.doi.org/10.1590/S0034-71081999000200014.

Bechara FC, Campos Filho EM, Barretto KD, Gabriel VA, Antunes AZ, Reis A. Unidades demonstrativas de restauração ecológica através de técnicas nucleadoras de biodiversidade. Revista Brasileira de Biociências 2007; 5(1): 9-11.

Boanares D, Azevedo CS. The use of nucleation techniques to restore the environment: a bibliometric analysis. Natureza \& Conservação 2014; 12(2): 93-98. http://dx.doi. org/10.1016/j.ncon.2014.09.002.

Boldrini II, Trevisan R, Schneider AA. Estudo florístico e fitossociológico de uma área às margens da lagoa do Armazém, Osório, Rio Grande do Sul, Brasil. Revista Brasileira de Biociências 2008; 6(4): 355-367.

Brighenti AM, Oliveira AF. Biologia de plantas daninhas. In: Oliveira RS Jr, Constantin J, Inque MH, editores. Biologia e manejo de plantas daninhas. Curitiba: Omnipax; 2011. p. 1-36.

Calegari L, Martins SV, Campos LC, Silva E, Gleriani JM. Avaliação do banco de sementes do solo para fins de restauração florestal em Carandaí, MG. Revista Árvore 2013; 37(5): 871-880. http://dx.doi.org/10.1590/S010067622013000500009 .

Corbin JD, Holl KD. Applied nucleation as a forest restoration strategy. Forest Ecology and Management 2012; 265: 37-46. http://dx.doi.org/10.1016/j.foreco.2011.10.013.

Empresa Brasileira de Pesquisa Agropecuária - EMBRAPA. Sistema Brasileiro de Classificação de Solos. 3. ed. Brasilia: Embrapa Solos; 2013. 353 p. 
Ferreira MC, Walter BMT, Vieira DLM. Topsoil translocation for Brazilian savanna restoration: propagation of herbs, shrubs, and trees. Restoration Ecology 2015; 23(6): 723 728. http://dx.doi.org/10.1111/rec.12252.

Ferreira PPA, Miotto STS. Sinopse das espécies de Ipomoea L. (Convolvulaceae) ocorrentes no Rio Grande do Sul, Brasil. Revista Brasileira de Biociências 2009; 7(4): 440-453.

Ferreira WG Jr, Schaefer CEGR, Silva AF. Uma visão pedogeomorfológica sobre as formações florestais da Mata Atlântica. In: Martins SV, editor. Ecologia de florestas tropicais do Brasil. Viçosa: UFV; 2012. p. 141-174.

Fowler WM, Fontaine JB, Enright NJ, Veber WP. Evaluating restoration potential of transferred topsoil. Applied Vegetation Science 2015; 18(3): 379-390. http://dx.doi. org/10.1111/avsc. 12162 .

Freitas WK, Magalhães LMS. Métodos e parâmetros para estudo da vegetação com ênfase no estrato arbóreo. Floresta e Ambiente 2012; 19(4): 520-540. http://dx.doi. org/10.4322/floram.2012.054.

Hall SL, Barton CD, Baskin CC. Topsoil seed bank of an Oak-Hickory forest in eastern Kentucky as a restoration tool on surface mines. Restoration Ecology 2010; 18(6): 834842. http://dx.doi.org/10.1111/j.1526-100X.2008.00509.x.

He M, Lv L, Li H, Meng W, Zhao N. Analysis on soil seed bank diversity characteristics and its relation with soil physical and chemical properties after substrate addition. PloS ONE 2016; 11(1): e0147439. http://dx.doi. org/10.1371/journal.pone.0147439.

Hutcheson KA. Test for comparing diversities based on the Shannon formula. Journal of Theoretical Biology 1970; 29(1): 151-154. http://dx.doi.org/10.1016/00225193(70)90124-4. PMid:5493290.

Instituto Brasileiro de Geografia e Estatística - IBGE. Manual técnico da vegetação brasileira [online]. Rio de Janeiro: IBGE; 2012 [cited 2015 Nov 20]. Available from: ftp://geoftp.ibge.gov.br/documentos/recursos_naturais/ manuais_tecnicos/manual_tecnico_vegetacao_brasileira.pdf

Long RL, Gorecki MJ, Renton M, Scott JK, Colville L, Goggin DE et al. The ecophysiology of seed persistence: a mechanistic view of the journey to germination or demise. Biological Reviews of the Cambridge Philosophical Society 2015; 90(1): 31-59. http://dx.doi.org/10.1111/brv.12095. PMid:24618017.

Longhi SJ, Araujo MM, Kelling MB, Hoppe JM, Müller I, Borsoi GA. Aspectos fitossociológicos de fragmento de Floresta Estacional Decidual, Santa Maria, RS. Ciência Florestal 2000; 10(2): 59-74. http://dx.doi. org/10.5902/19805098471.

Longhi SJ, Brun EJ, Oliveira DM, Fialho LEB, Wojciechowski JC, Vaccaro S. Banco de sementes do solo em três fases sucessionais de uma floresta estacional decidual em Santa Tereza, RS. Ciência Florestal 2005; 15(4): 359-370. http:// dx.doi.org/10.5902/198050981873.
Magurran AE. Medindo a diversidade biológica. Curitiba: Editora UFPR; 2013. 261 p.

Marchioretto MS, Miotto STS, Siqueira JC. Padrões de distribuição geográfica das espécies brasileiras de Pfaffia (Amaranthaceae). Rodriguésia 2009; 60(3): 667-681. http:// dx.doi.org/10.1590/2175-7860200960312.

Mendiburu F. Package 'agricolae'. R package version 1.2-1 [online]. 2015 [cited 2015 Nov 20]. Available from: http:// cran.r-project.org/web/packages/agricolae

Miranda A No, Kunz SH, Martins SV, Silva KA, Silva DA. Transposição do banco de sementes do solo como metodologia de restauração florestal de pastagem abandonada em Viçosa, MG. Revista Árvore 2010; 3(6): 1035-1043. http://dx.doi.org/10.1590/S0100-67622010000600009.

Monteiro KV, Blauth N. Os estados da Mata Atlântica: Rio Grande do Sul. In: Campanili M, Prochnow M. Mata atlântica - uma rede pela floresta. Brasília: RMA;2006.334 p.

Moro MF, Martins FR. Métodos de levantamento do componente arbóreo-arbustivo. In: Felfili JM, Eisenlohr PV, Melo MMRF, Andrade LA, Meira JAA No, editores. Fitossociologia no Brasil: métodos e estudos de casos. Viçosa: Editora UFV; 2011.556 p.

Piaia BB, Rovedder APM, Costa EA, Felker RM, Piazza EM, Stefanello MM. Transposição do banco de sementes para restauração ecológica da floresta estaciona no Rio Grande do Sul. Revista Brasileira de Ciências Agrárias 2017a; 12(2): 227-235.

Piaia BB, Rovedder APM, Stefanello MM, Felker RM, Piazza EM. Análise do banco de sementes visando estratégia de transposição para restauração ecológica no Rio Grande do Sul. Revista Floresta 2017b; 47(3): 221-228.

R Development Core Team. R: a language and environment for statistical computing. Vienna: R Foundation for Statistical Computing; 2013 [cited 2015 Nov 4]. Available from: http://www.R-project.org

Reis A, Bechara FC, Espindola MB, Vieira NK, Souza LL. Restauração de áreas degradadas: a nucleação como base para incrementar os processos sucessionais. Natureza \& Conservação 2003; 1(1): 28-36.

Reis A, Bechara FC, Tres DR, Trentin BE. Nucleação: concepção biocêntrica para a restauração ecológica. Ciência Florestal 2014; 24(2): 509-518. http://dx.doi. org/10.5902/1980509814591.

Rovedder APM, Piaia BB, Felker RM, Piazza EM, Hummel RB. Perspectivas da restauração ecológica de ecossistemas para o Rio Grande do Sul. In: Dörr AC, Rossato MV, Rovedder APM, Piaia BB, organizadores. Práticas e saberes em meio ambiente. Curitiba: Appris; 2014. 360 p.

Rovedder APM. Bioma Pampa: relações solo-vegetação e experiências de restauração. In: Anais [do] LXIV Congresso Nacional de Botânica: botânica sempre viva [e] XXXIII ERBOT Encontro Regional de Botânicos MG, BA 
e ES; 2013; Belo Horizonte. Belo Horizonte: Sociedade Botânica do Brasil; 2013. 220 p.

Sccoti MSV, Araujo MM, Wendler CFW, Longhi SL. Mecanismos de regeneração natural em remanescente de floresta estacional decidual. Ciência Florestal 2011; 21(3): 455-468. http://dx.doi.org/10.5902/198050983803.

Streck EV, Kampf N, Dalmolin RSD, Klamt E, Nascimento PC, Schneider E. et al. Solos do Rio Grande do Sul. 2. ed. Porto Alegre: EMATER/RS; 2008. 128 p.

Tozer MG, Mackenzie BDE, Simpson CC. An application of plant functional types for predicting restoration outcomes.
Restoration Ecology 2012; 20(6): 730-739. http://dx.doi. org/10.1111/j.1526-100X.2011.00828.x.

Triola MF. Introdução a estatística. 7. ed. Rio de Janeiro: LTC- Livros Técnicos e Científicos Editora S.A.; 1999. 410 p.

Tropicos.org. Tropicos [online]. Saint Louis: Missouri Botanical Garden; 2016 [cited 2016 Oct 10]. Available from: http://www.tropicos.org

Zhang ZQ, Shu WS, Lan CY, Wong MH. Soil seed bank as an input of seed source in revegetation of Lead/Zinc Mine tailings. Restoration Ecology 2001; 9(4): 378-385. http://dx.doi.org/10.1046/j.1526-100X.2001.94007.x. 